\title{
Удосконалення режимних параметрів водоаміачних абсорбційних холодильних агрегатів, працюючих у широкому діапазоні температур навколишнього середовища
}

\author{
І. М. Іиенко, О. С. Тімлов \\ Одеська національна академія харчових технологій, вул. Канатна, 112, Одеса, 65039, Україна \\ ORCID: ${ }^{1}$ 0000-0003-1908-5713; $₫$ e-mail: titlov1959@gmail.com
}

\begin{abstract}
Абсорбиійні холодильники можуть знайти широке застосування при роботі в широкому діапазоні температур повітря навколишнєго середовища. Для вирішення ряду технічних завдань по оптимізації енергетичних характеристик були виконані теоретичні дослідження ичилів і прочесів тепломасообміну в ряді ключових елементів (випарнику, абсорбере, генераторі), а також експериментальні дослідження серійної моделі Васильківського заводу холодильників. Показано, шьо зміна складу робочого тіла (тиску інертного газу) при зміні температур зовнішнього повітря дозволяє стабілізувати енергоспоживання, незважаючи на ряд негативних впливів на робочі параметри. За результатами досліджень були запропоновані два енергозберігаючих способу управління водоаміачнимі абсорбиійними холодильними агрегатами.
\end{abstract}

Ключові слова: водоаміачні абсорбиійні холодильні агрегати; моделювання процесів тепло масообміну; термодинамічні циикли; енергозбереження; иирокий діапазон температур навколишнього середовища.

(C) The Author(s) 2018. This article is an open access publication

This work is licensed under the Creative Commons Attribution 4.0 International License (CC BY) http://creativecommons.org/licenses/by/4.0/

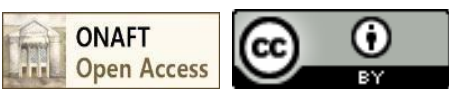

\section{Вступ}

Закон «Про продовольчу безпеку України» [1] передбачає формування мереж заготівельних пунктів, створення умов для розширення чисельності об'єктів торгової інфраструктури, покращення транспортного доступу віддалених територій для гарантованого забезпечення основними видами харчових продуктів. Реалізація цих заходів передбачає створення безперервного холодильного ланцюга, елементом якого $\epsilon$ і транспортні холодильники.

Застосування компресійних холодильників в усіх випадках передбачає наявність електричної енергії і певних температурних умов при експлуатації. Також для надійної роботи компресійних холодильників потрібна і певна температура навколишнього середовища, яка виключає загустіння мастила в компресорі. Наприклад, сучасні нормативні документи допускають роботу компресорів у складі холодильних агрегатів тільки при температурі навколишнього повітря вище плюс $10{ }^{\circ} \mathrm{C}$ [2].

Цікаві рішення завдань низькотемпературного зберігання в транспортних умовах можуть бути знайдені за допомогою тепловикористовуючих холодильних машин, які можуть працювати на неелектричних джерелах теплової енергії, у тому числі і на непридатних джерелах тепла, а найбільші перспективи серед них мають водоаміачні абсорбційні холодильні агрегати безнасосного типу - далі ВАХА.

ВАХА працюють на широкодоступному природному робочому тілі - водоаміачному розчині (BAР) 3 інертним газом - воднем. Транспортні умови (тряска, на- хили) не чинять несприятливої дії на робочі характеристики ВАХА [3].

Відсутність рухомих елементів в складі конструкції, абсолютна автономність роботи ВАХА і можливість використання будь-яких джерел теплової енергії для отримання штучного холоду відкриває нові перспективи їх застосування. Зокрема, Старостенко I.В. [4] пропонує використовувати їх унікальні можливості в системах отримання води 3 атмосферного повітря в місцях 3 дефіцитом водних ресурсів (країни Північної Африки, Аравійського півострова, Близького Сходу та ін.).

В той же час BAXА, незважаючи на ряд переваг при роботі у транспортних умовах, мають підвищене, у порівнянні з компресійними аналогами, енергоспоживання при експлуатації через недосконалості тепловикористовуючого абсорбційного холодильного циклу і наявності дифузійних процесів тепломасообміну у випарнику і абсорбері [5].

Сучасні BAXА також як і їх компресійні аналоги мають обмеження по нижній межі температури повітря навколишнього середовища, що може стримувати їх широке використання у складі безперервного холодильного ланцюга.

Таким чином, актуальними стають роботи з удосконалення режимних параметрів ВАХА, працюючих у широкому діапазоні температур навколишнього середовища.

\section{1 Основний зміст роботи}

Для оцінки перспектив використання ВАХА при роботі в широкому діапазоні експлуатаційних параметрів, 
проведено моделювання i аналіз їх термодинамічних циклів і процесів тепло- i масообміну в основних їх елементах.

Початковими даними для розрахунку і аналізу термодинамічних циклів являються: температура охолоджувального середовища $t_{W}$; температура об'єкта охолодження $t_{o b}$; температурні напори на елементах, які неявно враховують умови теплообміну і недорекуперацію тепла: $\Delta t_{h}$ - температурний напір між слабким ВАР і гріючим джерелом тепла; $\Delta t_{W K}, \Delta t_{W A}, \Delta t_{\text {де }}$ - температурний напір в конденсаторі, абсорбері, дефлегматорі і охолоджувальним середовищем; $\Delta t_{T O}$ - температурний напір між потоками слабкого і міцного ВАР на холодному кінці РТР; холодопродуктивність випарника $Q_{0}$. Змінним параметром при аналізі являється температура джерела тепла $t_{h}$.

Аналіз результатів розрахунку (рис.1) дозволяє зробити наступні висновки.

У діапазоні розрахункових параметрів має місце максимум енергетичної ефективності ВАХА. Найбільш явна наявність максимуму для умов роботи при температурах охолоджувального середовища $20 \ldots 32{ }^{\circ} \mathrm{C}$ і низьких температурах об'єкта охолодження (мінус $25{ }^{\circ} \mathrm{C}$ ). При зниженні температур об'єкта охолодження максимум енергетичної ефективності зміщується в область високих температур гріючого середовища, а його чисельні значення зменшуються. Так, наприклад, при температурі охолоджувального середовища $26{ }^{\circ} \mathrm{C}$ і температурі об'єкта охолодження мінус $5{ }^{\circ} \mathrm{C}$ максимум теплового коефіцієнта має місце при температурі джерела тепла $110{ }^{\circ} \mathrm{C}$, при мінус $15{ }^{\circ} \mathrm{C}$ - при $120{ }^{\circ} \mathrm{C}$, при мінус $25{ }^{\circ} \mathrm{C}$ - при $140{ }^{\circ} \mathrm{C}$, відповідно значення теплового коефіцієнта складають: 0,$53 ; 0,44 ; 0,34$.

Аналіз результатів розрахунку показав, що такий хід залежностей пояснюється: а) в області низьких температур гріючого середовища (до максимуму теплового коефіцієнта) - високою кратністю циркуляції ВАР між генератором і абсорбером (від 6 до 112), яка зумовлена вузькою областю дегазації $\left(\Delta \xi=\Delta \xi_{\kappa p}-\xi_{c л}\right)-$ $\Delta \xi=0,006 \ldots 0,033 ;$ б) в області високих температур гріючого середовища - збільшенням частини води в паровій суміші, що виходить 3 генератора, - наприклад при температурі охолоджуючого середовища $26{ }^{\circ} \mathrm{C}$ i температурі об'єкта охолодження мінус $5{ }^{\circ} \mathrm{C}$ зростання долі пари води в суміші складає від 0,036 до 0,408 , тобто більше, ніж в 10 разів.

У першому випадку мають місце додаткові теплоприпливи в генератор з потоком міцного ВАР. У другому випадку, незважаючи на зниження кратності циркуляції ВАР, теплове навантаження в генераторі збільшується через додаткові витрати на випаровування абсорбенту. Зростання теплового навантаження дефлегматора при цьому, відповідно також збільшується більше, ніж в 10 разів (при температурі охолоджувального середовища $26{ }^{\circ} \mathrm{C}$ і температура об'єкта охолодження мінус $5{ }^{\circ} \mathrm{C}$ - від 0,024 кДж/кг до 2,200 кДж/кг).

Зменшення теплового коефіцієнта циклу ВАХА при зниженні рівня температур охолодження пояснюється тим, що для реалізації низькотемпературного циклу потрібен ВАР $з$ підвищеною долею абсорбенту в абсорбері, а це пов'язано з додатковим випаровуванням води в генераторі. Так, наприклад, при температурі охолоджувального середовища $26{ }^{\circ} \mathrm{C}$ зниження температури об'єкту охолодження від мінус $5{ }^{\circ} \mathrm{C}$ до мінус $25{ }^{\circ} \mathrm{C}$ вимагає зниження долі аміаку в слабкому ВАР від 0,439 до 0,129 [6].

Для оцінки енергетичних перспектив зміни складу робочого тіла ВАХА в частині зменшення кількості інертного газу (зниження тиску в системі) при зниженні температури охолоджуючого середовища було виконано моделювання і аналіз процесів тепло- і масообміну в основних елементах BAXА (абсорбері, випарнику і генераторі).

Абсорбер ВАХА. Система рівнянь, які описують процеси тепло- і масообміну на елементарній ділянці $d x$ має вигляд :

a) рівняння балансу маси:

$$
-G_{0} \cdot d Y=k_{A} \cdot\left(y-y^{*}\right) \cdot \psi \cdot d F
$$

б) рівняння балансу тепла між потоками ПГС і ВАР:

$$
G_{0} \cdot c_{p}^{\prime} \cdot d t=\alpha \cdot(\vartheta-t) \cdot \psi \cdot d F
$$

в) рівняння теплопередачі між потоком ВАР і навколишнім середовищем:

$$
k \cdot(\vartheta-\Theta) \cdot d F^{\prime}=d Q_{A} ;
$$

Рівняння теплового балансу на ділянці $d x$ :

$$
-G_{0} \cdot q_{\text {абс }} \cdot d Y=G_{0} \cdot c_{p}^{\prime} \cdot d t-G_{B A P} \cdot c_{B A P} \cdot d \vartheta+\cdot d Q_{A} ;
$$

де $\mathrm{k}_{A}$ - коефіцієнт масопередачі при абсорбції пари аміаку з парогазової суміші (ПГС) слабким ВАР; $\alpha$ коефіцієнт теплообміну між потоками ВАР і ПГС; $k$ коефіцієнт теплопередачі від потоку ВАР до охолоджуючого середовища; $\theta$ - температура охолоджуючого середовища; $t$ - поточна температура потоку ПГС; $\vartheta$ - поточна температура потоку ВАР; $G_{0}$ - масові витрати інертного газу-водню, кг/с; $\Psi$ - поверхня теплообміну, яка приходиться на одиницю поверхні зіткнення фаз (цівки рідини і потоку ПГС); $d F=d x \cdot \pi \cdot d_{6 \mu}$ - площа елементарної ділянки внутрішньої поверхні труби абсорбера, м $2 ; d F^{\prime}=d x \cdot \pi \cdot d_{\text {нар }}$ - площа елементарної ділянки зовнішньої труби абсорбера, ${ }^{2} ; G_{B A P}$ - поточні масові витрата ВАР, кг/с; $C_{B A P}-$ масова теплоємність ПГС; $y$ - поточна масова доля аміаку в ПГС; $y^{*}$ - поточна масова доля аміаку в ПГС, рівноважна 3 насиченою рідиною ВАР при температурі $v$ і масовій долі аміаку $y ; Y$ - поточна масова доля аміаку в ПГС, яка являє собою відношення маси аміаку до маси газу-носія (вод-

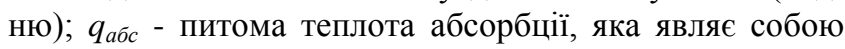
суму питомої теплоти фазового переходу пари в рідину і теплоту змішування поглиненої рідини у розчинах $\left(q_{\text {абс }}=f(v, y)\right)$.

У систему(1) - (4) включають і рівняння зв'язку між складом ПГС в різних формах і фазової рівноваги ВАР, а також рівняння балансу маси між потоками робочого тіла.

Рішення системи рівнянь (1) - (4) дозволяє визначити параметри потоків робочого тіла - ПГС $\left(G^{\prime \prime}{ }_{\Pi Г C}, y^{\prime \prime}{ }_{П Г C}\right.$, $\left.t^{\prime \prime}\right)$ і ВАР $\left(G_{B A P}^{\prime \prime}, y_{B A P}^{\prime \prime}, v^{\prime \prime}\right)$ після їх контактної взаємодіï.

Для енергетичного аналізу циклу інтерес, в першу чергу, представляють параметри потоку ПГС, зокрема міри очищення ПГС в абсорбері $\left(y^{\prime \prime} п г\right)$. 

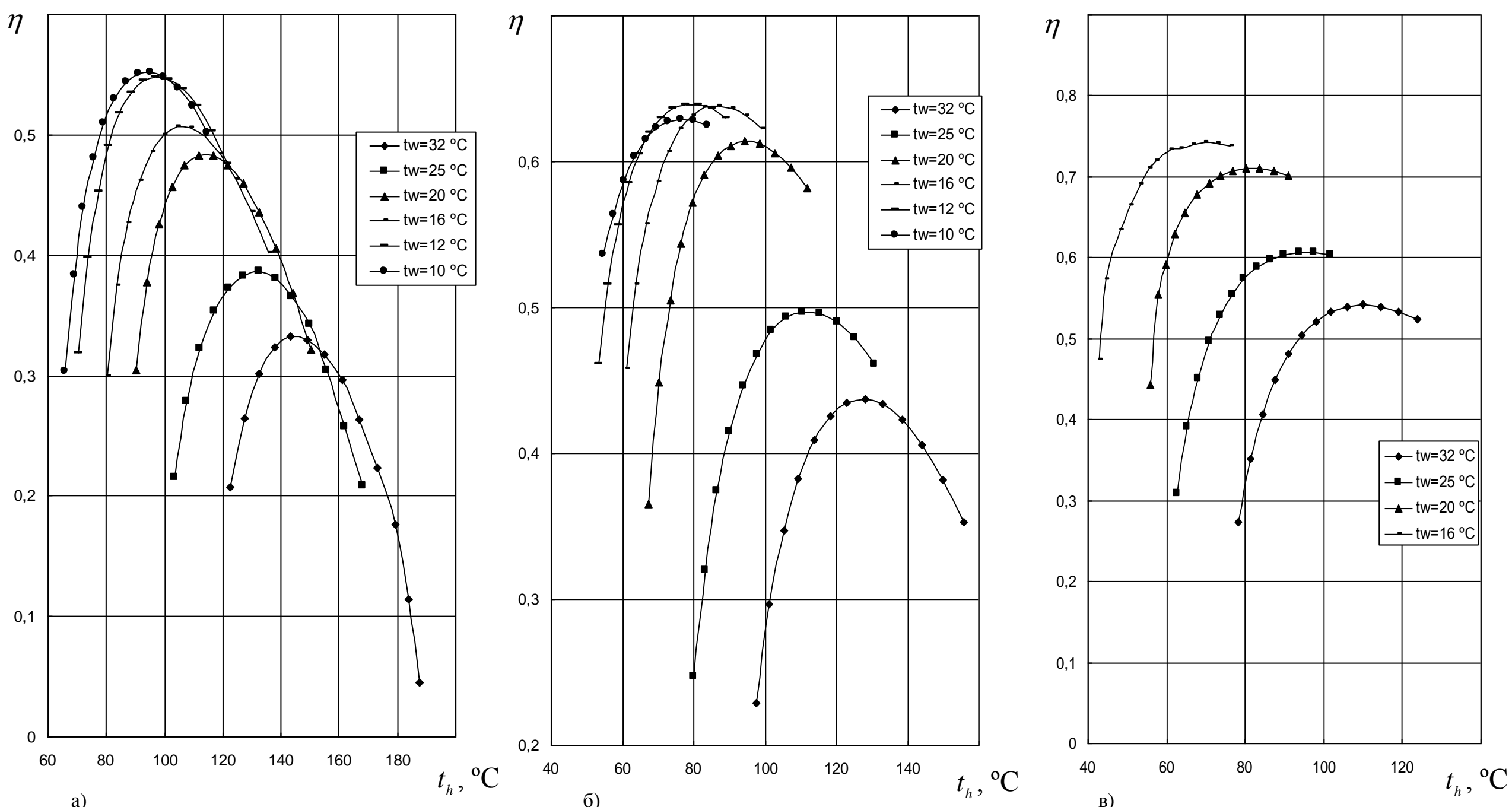

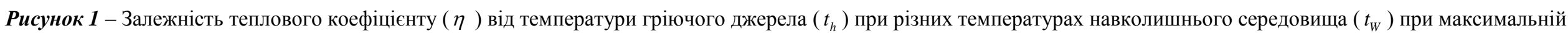
температурі випаровування : а) $t_{\max }=$ минус $10{ }^{\circ} \mathrm{C}$; б) $t_{\max }=0{ }^{\circ} \mathrm{C}$; в) $t_{\max }=10^{\circ} \mathrm{C}$ 
Рішення системи (1) - (4) з урахуванням рівняння зв'язку проводилося за допомогою бібліотеки вбудованих функцій "Differential Equation Solving" в системі Mathcad методом Рунге - Кутта 3 автоматичним вибором кроку при загальній довжині труби абсорбера 4,8 м. При розрахунках приймалася постійність температури навколишнього середовища $\theta=$ const, а при визначенні коефіцієнта теплопередачі між цівкою рідкого BAP i навколишнім середовищем, термічним опором стінки труби абсорбера нехтували, тобто перепад температур визначався різницею $v^{\prime}-\theta$.

Відведення тепла абсорбції до навколишнього середовища в традиційних схемах здійснюється в режимі природної конвекції. В зв'язку з цим в систему рівнянь була додана залежність коефіцієнта теплообміну на зовнішній поверхні труби абсорбера від різниці температур.

Було показано, що при збільшенні тиску в системі має місце зниження інтенсивності процесу масопереносу в абсорбері BAXA [7].

Випарник ВАХА. Тепло - і масообмін в елементарній ділянці випарника $d x$ може бути описаний системою диференціальних рівнянь :

$$
\begin{gathered}
G_{0} \cdot d Y=\beta \cdot\left(y^{*}-y\right) \cdot d F \\
G_{0} \cdot C_{P}^{\prime} \cdot d t=\alpha \cdot(t-\vartheta) \cdot d F \\
d Q_{0}=k \cdot \psi \cdot(\theta-\vartheta) \cdot d F
\end{gathered}
$$

де $\beta$ - коефіцієнт масообміну при випаровуванні аміаку в ПГС; $\alpha$ - коефіцієнт теплообміну між цівкою аміаку і потоком ПГС; $k$ - коефіцієнт теплопередачі від аміаку до охолоджувального об'єкту; $\psi$ - поверхня охолодження, яка приходиться на одиницю поверхні дотикання фаз; $\theta$ - температура об'єкту охолодження; $t$ поточна температура ПГС; $\vartheta$ - поточна температура випаровування аміаку; $G_{0}$ - масові витрати водню; $C_{P}^{\prime}$ масова теплоємність ПГС; $y$ - поточна масова доля аміаку в ПГС; $y^{*}$ - поточна масова доля аміаку в ПГС, рівноважна $з$ насиченою рідиною аміаку; $Y$ - поточна масова відносна доля аміаку в ПГС, що являє собою відношення маси аміаку до маси газу-носія (водню); $Q_{0}$ - холодопродуктивність випарника; $d F$ - площа тепломасообміну елементарної ділянки випарника $d x$.

Співвідношення (5) яке входить в систему диференціальних рівнянь, визначає тепло- і масообмін при випаровуванні аміаку в ПГС, рівняння (6) - теплообмін між аміаком і ПГС, рівняння (7) - теплопередачу від аміаку, що випаровується, до об'єкту охолодження. Рівняння (7) описує теплопередачу між аміаком, що випаровується, і об'єктом охолодження (холодильною камерою) з фіксованою температурою $\theta_{0}$.

Для знаходження шести невідомих параметрів $\vartheta, t$, $Q_{o}, Y, y, y^{*}$ утворюють систему 3 шести рівнянь. Два рівняння, яких не вистачає, виражають зв'язок між $y^{*}$ i $\vartheta$, а також між $y$ і $Y$ :

$$
\begin{gathered}
y=\frac{Y}{1+Y} ; \\
y^{*}=A_{0}+A_{1} \cdot \vartheta+A_{2} \cdot \vartheta^{2}+\ldots+A_{n} \cdot \vartheta^{n}
\end{gathered}
$$

де $A_{0}, A_{1}, \ldots, A_{n}$ - сталі, які залежать від властивостей речовини.

Шосте рівняння - рівняння теплового балансу:

$r \cdot \beta \cdot\left(y^{*}-y\right) \cdot d F=k \cdot \psi \cdot(\theta-\vartheta) \cdot d F+\alpha \cdot(t-\vartheta) \cdot d F$

Виконується рішення системи (5) - (8) у разі перевірочного розрахунку випарника, коли задані його геометричні параметри діаметр $\left(d_{\text {вн }} / d_{\text {нар }}\right)$ і довжина $\left(l_{\text {uсn }}\right)$. При прямотоці задані на вході випарника початкові умови: $G_{0}, \vartheta_{1}, t_{1}, y_{1}$, і масові витрати рідкого аміаку $L_{o}$. Використовуючи метод Ейлера задаються приростом $\Delta F$ і визначають за рівняннями (5) - (7) прирости:

$$
\begin{gathered}
\Delta Y=a \cdot\left(y^{*}-y\right) \cdot \Delta F \\
\Delta t=b \cdot(t-\vartheta) \cdot \Delta F \\
\Delta Q_{0}=r \cdot(\theta-\vartheta) \cdot \Delta F .
\end{gathered}
$$

Знайшовши прирости, розраховують значення параметрів, що відповідають приросту $\Delta F$ :

$$
Y=Y_{1}+\Delta Y \quad t=t_{1}+\Delta t \quad Q_{0}=Q_{0(1)}+\Delta Q_{0}
$$

Поточному значенню параметрів $Y, t, \theta$ відповідають температура випаровування аміаку $\vartheta$, яка визначається 3 рівняння теплового балансу (10) з урахуванням (9):

$$
\begin{aligned}
& r \cdot \beta \cdot\left(A_{0}+A_{1} \cdot \vartheta+A_{2} \cdot \vartheta^{2}+\ldots+A_{n} \cdot \vartheta^{n}\right) \cdot y= \\
& =k \cdot \psi \cdot(\theta-\vartheta)+\alpha \cdot(t-\vartheta)
\end{aligned}
$$

За значенням $\vartheta$ знаходимо рівноважну долю аміаку $y^{*}$. Далі задаємося новим приростом $\Delta F$ і аналогічно розраховуємо наступну ділянку $d x$, приймаючи параметри, знайдені в результаті розрахунку першої ділянки, за початкові. Розрахунок ведеться до досягнення кінця випаровування, а сумарну холодопродуктивність знаходимо, сумуючи значення $d Q_{0(i)}$ по ділянках $d x$.

Показано, що із зростанням тиску в системі ВАХА від 10 до 20 бар інтенсивність процесів тепломасообміну при випаровуванні аміаку в ПГС знижується в усьому діапазоні режимних параметрів. Так, значення коефіцієнтів масообміну знижуються в $1,75 \ldots 1,78$, а коефіцієнтів теплообміну - в 2,71...2,88 разів.

Генератор ВАХА. Для оцінки енергетичної ефективності режимів роботи генератора ВАХА при різних рівнях тиску в системі був проведений відповідний аналіз, при якому були враховані результати експериментальних досліджень серійних ВАХА виробництва B3X з $U$ - подібним барботажним горизонтальним ректифікатором.

Початкові дані були задані таким чином. На вхід термосифону ВАХА поступає міцний ВАР із стандартною масовою долею аміаку $y^{\prime}=0,35$ і температурою $t_{T C}^{\prime}$. Розчин містить 1 кг аміаку. 3 термосифону при температурі кінця кипіння $t_{T C}^{\prime \prime}$ виходить слабкий ВАР 3 постійною масовою долею аміаку $y^{\prime \prime}=0,15$ і парова суміш, зі змінною залежно від тиску в системі, масовою долею аміаку $y_{c м}$. Тиск в системі змінюється від 12 до 20 бар.

Практична постійність складу ВАР у робочому режимі ВАХА на вході - виході термосифону забезпечується за рахунок установки спеціального каналу рідкого аміаку між конденсатором і входом випарника, що виконує роль ресивера рідкого аміаку. 
3 урахуванням залежності термодинамічних і теплофізичних властивостей ВАР від температури і складу суміші визначена кількість пари аміаку в паровій суміші на виході термосифону $\left(m_{X}^{\prime \prime}\right)$. За величиною $m_{X}^{\prime \prime}$ можна судити і про холодопродуктивність і про енергетичну ефективність режимів роботи.

При розрахунку і аналізі використовувалися термодинамічні властивості ВАР у різних режимах роботи (таблиця. 1).
Аналіз отриманих результатів дозволяє зробити висновок про сприятливий вплив зниження рівня тиску на енергетичну ефективність генератора BAXА. Так, при зниженні тиску від 20 бар до 12 бар питомі витрати тепла на випаровування 1 кг аміаку знижуються на $7,8 \%$.

Приведені результати експериментальних досліджень енергетичних параметрів ВАХА, працюючих в широкому діапазоні температур навколишнього середовища.

Таблиця 1 - Розрахункові характеристики потоків ВАР на виході генератора в різних режимах роботи (по рівню тиску в системі)

\begin{tabular}{|c|c|c|c|c|c|}
\hline Розрахункові параметри & \multicolumn{5}{|c|}{ Тиск, бар } \\
\cline { 2 - 6 } & 20 & 18 & 16 & 14 & 4048 \\
\hline $\begin{array}{c}\text { Ентальпія паро-рідинної суміші } \\
\text { ВАР на виході з генератора, кДж }\end{array}$ & 4647 & 4511 & 4409 & 4235 & 2536 \\
\hline $\begin{array}{c}\text { Ентальпія рідкого ВАР на вході в } \\
\text { генератор, кДж }\end{array}$ & 2969 & 2883 & 2791 & 2697 & 1485 \\
\hline $\begin{array}{c}\text { Кількість підведеного тепла в ге- } \\
\text { нераторі, кДж }\end{array}$ & 1678 & 1628 & 1618 & 1538 & 2063 \\
\hline $\begin{array}{c}\text { Питома кількість затраченого теп- } \\
\text { ла в генераторі, кДж/кг }\end{array}$ & 2237 & 2200 & 2186 & 2107 & \\
\hline
\end{tabular}

У якості об'єктів досліджень використовували побутовий абсорбційний холодильник з ВАХА, виготовлений на В3Х із застосуванням серійних технологій, однокамерний холодильник 3 низькотемпературним відділенням (НТВ) типу «Київ-410» АШ- 160.

Додатково НТВ, виконаного у вигляді алюмінієвого короба, була встановлена П - подібна теплова труба (TT) $з$ аксіальними канавками і з аміаком в якості робочого тіла. Зовнішній діаметр ТТ 12 мм. Матеріал корпусу - алюміній. Конденсатор ТТ кріпиться до задньої стінки короба НТВ, а випарні зони ТТ закріплені на бічних стінках короба.

Було проведено вивчення пускових режимів холодильника із «отепленого стану» - від температури навколишнього середовища. На рис. 2 представлені графіки функцій середніх температур в ХК і НТВ - $f_{4}(\tau)$ i $f_{5}(\tau)$, відповідно, для усього діапазону значень теплової потужності генератора. 3 графіку видно, що зі збільшенням потужності генератора час виходу холодильного приладу на стаціонарний режим залишається практично однаковим, але при цьому відбувається значне (на $5 \ldots 9^{\circ} \mathrm{C}$ ) зниження рівня температур в охолоджувальних камерах.

Аналіз результатів експериментальних досліджень показує зниження рівня температур в НТВ до мінус $21 \ldots$ мінус $18^{\circ} \mathrm{C}$ при температурі навколишнього повітря $32{ }^{\circ} \mathrm{C}$. Таким чином холодильник по існуючому нормативному документу переходить 3 класу «**» (3 температурою в НТВ не вище мінус $12^{\circ} \mathrm{C}$ ) в клас «***» (

3 використанням результатів тестових експериментальних досліджень за оригінальною авторською методикою були отримані розрахункові залежності теплопрохідності $(K F)$ охолоджуваних камер абсорбційного холодильного приладу від чисельних значень корисного об'єму, у тому числі і при різних температурах повітря навколишнього середовища. 3 їх допомогою були визначені тепло притоки $\left(Q_{T \Pi}\right)$ в охолоджувані камери
(НTB і ХК) в діапазоні температур повітря навколишнього середовища $10 \ldots 32^{\circ} \mathrm{C}$.

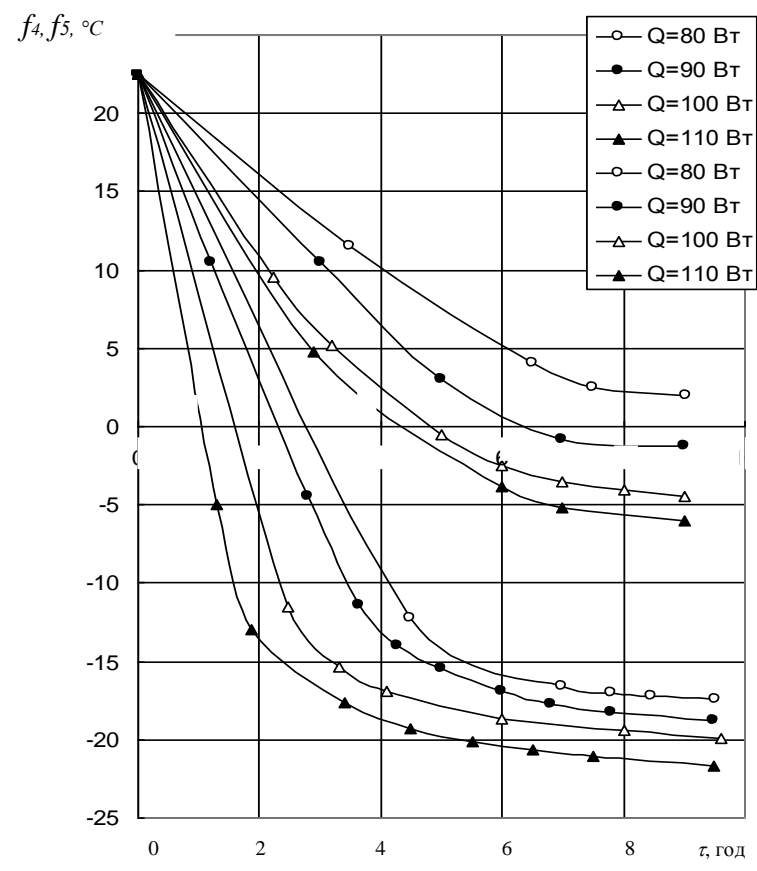

Рисунок 2 - Пускові характеристики об'єкту дослідженнями 3 «отепленого стану».

Результати розрахунків приведені на рисунку 3. При розрахунку теплоприпливів температура в НТВ приймалася рівною мінус $18^{\circ} \mathrm{C}$, а в ХК - плюс $5^{\circ} \mathrm{C}$.

Аналіз результатів розрахунку, приведених на рис.3, показав, що в діапазоні температур експлуатації об'єкту дослідження, відповідному класу $S N$ (від 10 до $32^{\circ} \mathrm{C}$ ) теплоприпливів в камери зростають приблизно в 3 рази. 


\section{$Q_{T \Pi}, \mathrm{BT}$}

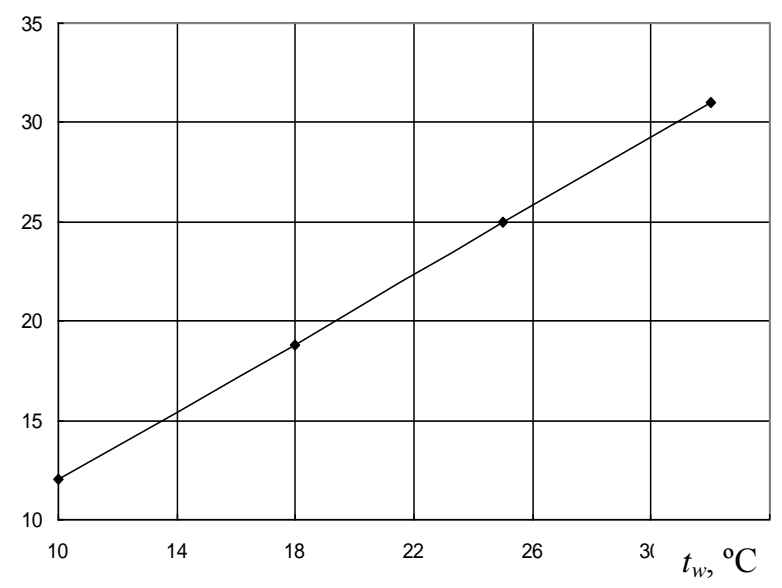

Рисунок 3 - Розрахункова залежність сумарних теплопритоків до охолоджуваних камер об'єкту дослідження від температури повітря в приміщені.

Для вивчення перспектив вимушеного обдуву теплорозсіюючих елементів ВАХА (абсорбера і конденсатора) були проведені відповідні експериментальні дослідження [8]. Слід зазначити, що нині енергетична доцільність застосування вимушеного обдування теплорозсіюючих елементів холодильників 3 ВАХА недостатньо очевидна. Відомі не лише дослідження, що підтверджують перспективність зовнішнього вимушеного обдуву, але і роботи, застосування вентиляторів, що заперечують корисність, у ВАХА.

В об'єкті дослідження вентилятор встановлювався в повітряний розтруб, який кріпився в зоні абсорбера i конденсатора. Підйомна ділянка дефлегматора охолоджувалася в режимі природної конвекції. Результати випробувань об'єкту дослідження з обдуванням теплорозсіюючих елементів приведені на рис.4. і рис.5.

При аналізі енергетичної ефективності використовувався середньодобовий тепловий коефіцієнт $(\eta)$, що

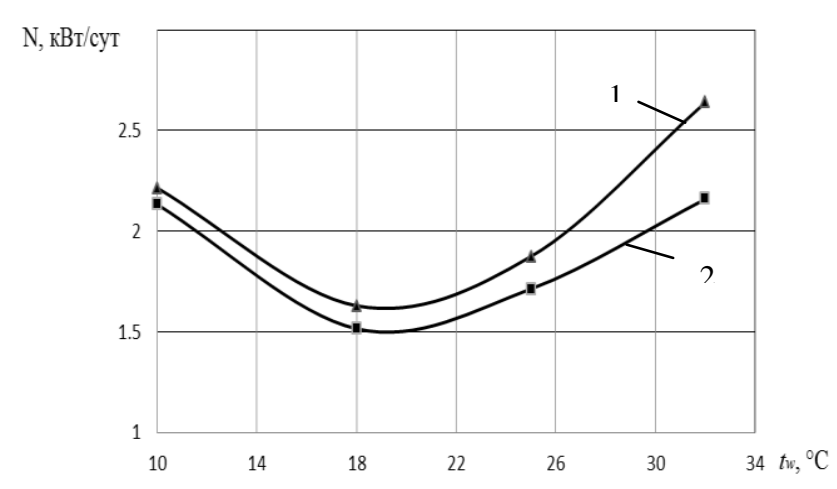

Рисунок 4 - Залежність добового енергоспоживання об'єкту дослідження від температури повітря в приміщенні. Робочий тиск в системі 20 бар. Режим роботи позиційний: 1 - робота без обдуву теплорозсіюючих елементів; 2 - робота 3 обдувом теплорозсіюючих елементів. дозволяє враховувати позиційний режим управління об'єктом дослідження, тобто непостійність підведення теплової потужності в генераторі ВАХА.

Аналіз результатів, представлених на рис.4 і рис.5, показав, що в діапазоні температур повітря навколишнього середовища від 10 до $32{ }^{\circ} \mathrm{C}$ має місце мінімум енергоспоживання ВАХА 3 традиційним робочим тілом. Як у разі обдування, так і без нього, мінімум енергоспоживання лежить в діапазоні температур повітря навколишнього середовища від 18 до $21^{\circ} \mathrm{C}$.

Зростання енергоспоживання в області низьких температур зовнішнього повітря пов'язане зі значними втратами аміаку при його додатковій конденсації в транспортному каналі, незважаючи на зниження теплоприпливів в охолоджуючих камерах і сприятливі умови для відведення тепла від абсорбера i конденсатора. Окрім цього мають місце і додаткові витрати енергії в період запуску ВАХА для прогрівання елементів генераторного вузла і транспортних магістралей. Так, при температурі зовнішнього повітря $10^{\circ} \mathrm{C}$ енергоспоживання, в порівнянні з оптимальним діапазоном температур від 18 до $22{ }^{\circ} \mathrm{C}$, зростає до $47 \%$.

Зростання енергоспоживання в зоні підвищених температур зовнішнього повітря пов'язане з додатковим випарюванням пари води через зростання температури генерації, зі зниженням ефективності процесів тепловідводу на теплорозсіюючих елементах (дефлегматорі, абсорбері і конденсаторі) і зростанням теплоприпливів в охолоджувані камери із навколишнього середовища. При температурі зовнішнього повітря $32{ }^{\circ} \mathrm{C}$ енергоспоживання зростає до 76 \%, в порівнянні з оптимальним діапазоном температур від 18 до $22{ }^{\circ} \mathrm{C}$, за відсутності зовнішнього обдуву і до 46 \% - при зовнішньому обдуві.

При аналізі слід зазначити, що максимальний ефект від вимушеного обдуву має місце при підвищених температурах зовнішнього повітря, що узгоджується 3 результатами інших дослідників. Так, в діапазоні температур зовнішнього повітря від $10{ }^{\circ} \mathrm{C}$ до $26^{\circ} \mathrm{C}$ корисний енергетичний ефект від вимушеного обдуву складає $7 \ldots 11 \%$, а при підвищених температурах повітря збільшується до $22 \%$.

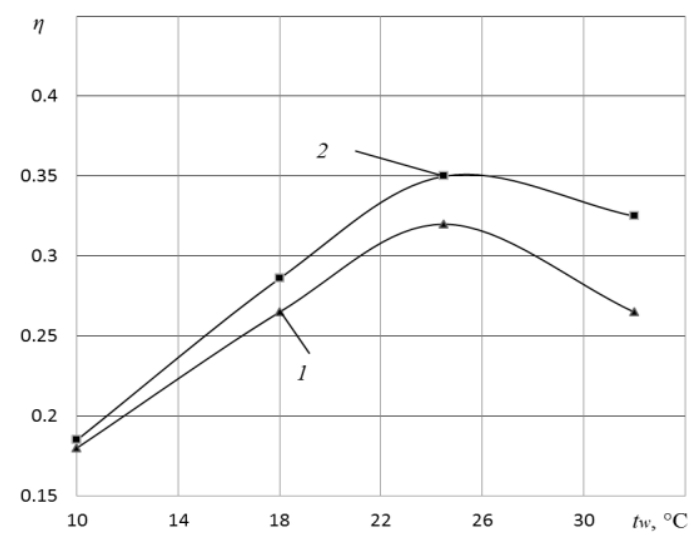

Рисунок 5 - Залежність середньодобового теплового коефіцієнта об'єкту дослідження від температури повітря в приміщенні при номінальному тепловому навантаженні 110 Вт і позиційному управлінні. Робочий тиск в системі 20 бар: 1 - робота без обдуву теплорозсіюючих елементів; 2 - робота 3 обдувом теплорозсіюючих елементів. 
На наступному етапі експериментальних досліджень проводилася перевірка результатів математичного моделювання по впливу рівня тиску в системі на енергетичну ефективність ВАХА.

Були проведені випробування об'єкту дослідження 3 різними рівнями тиску робочого тіла в системі: $20 \pm 0,1$ бар (традиційна заправка для кліматичних умов Украї-

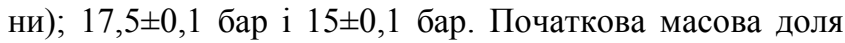
аміаку у ВАР не змінювалася і складала $35 \%$.

У діапазоні температур зовнішнього повітря $17 \ldots 19{ }^{\circ} \mathrm{C}$ в об'єкті дослідження з тиском 17,5 бар зафіксовано мінімальне добове енергоспоживання 1,420 кВт·год, що на 7 \% менше, ніж при цих же самих умовах у моделі 3 традиційним базовим тиском 20 бар (рис.6). Середньодобовий тепловий коефіцієнт склав 0,36 (рис.7).

Вимушений обдув додатково понизив добове енергоспоживання до 1,350 кВт·год, що в порівнянні з базовою моделлю склало економію енергоспоживання до $10 \%$.

Дослідження також показали, що ВАХА $з$ початковим (заправним) тиском 17,5 бар припиняв роботу при температурах зовнішнього повітря понад $27^{\circ} \mathrm{C}$ без зовнішнього обдуву теплорозсіюючих елементів, а при обдуві - $329^{\circ} \mathrm{C}$.

Така ситуація пов'язана 3 недостатньою мірою стискування пари аміаку в конденсаторі. Робочий тиск в системі (17,5 бар) не забезпечує умови конденсації (температурний напір) пари аміаку з відповідним відведенням теплоти фазового переходу в навколишнє середовище. В цьому випадку пари аміаку виходить за межі конденсатора у випарник і порушує циркуляцію ПГС в контурі природної циркуляції (КПЦ) ВАХА.

Наявність вимушеного обдуву збільшує температурний напір і робоча зона ВАХА дещо зміщується у бік підвищених температур зовнішнього повітря - при тиску 17,5 бар до $29^{\circ} \mathrm{C}$.

При температурі зовнішнього повітря $10{ }^{\circ} \mathrm{C}$ в об'єкті дослідження 3 тиском 15 бар зафіксоване мінімальне добове енергоспоживання 1,275 кВт·год, що на $77 \%$ менше, ніж в цих же умовах у моделі з традиційним

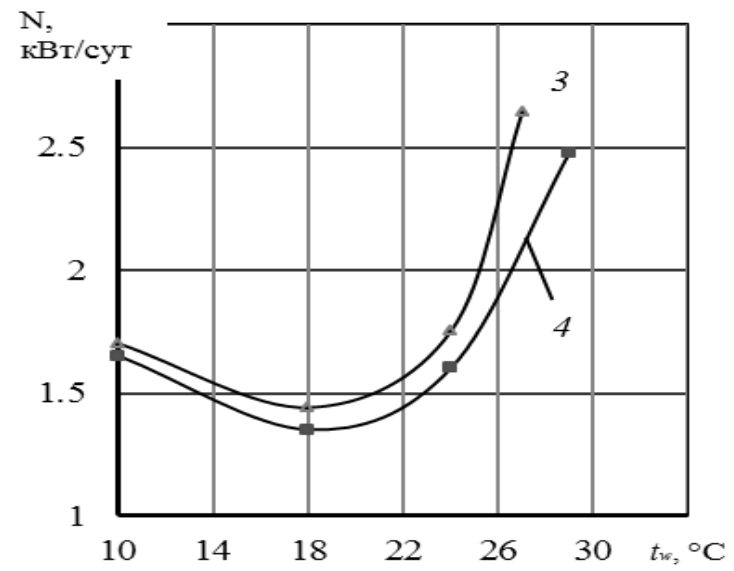

Рисунок 6 - Залежність добового енергоспоживання об'єкту дослідження від температури повітря в приміщенні. Робочий тиск в системі 17,5 бар. Режим роботи позиційний: 3 - робота без обдуву теплорозсіюючих елементів; 4 - робота $з$ обдувом теплорозсіюючих елементів. базовим тиском 20 бар (рис.8). Середньодобовий тепловий коефіцієнт склав 0,26 (рис.9).

Вимушений обдув додатково знизив добове енергоспоживання до 1,215 кВт·год, що в порівнянні з базовою моделлю складе економію енергоспоживання до $81 \%$. Максимальне чисельне значення середньодобового теплового коефіцієнта мало місце в діапазоні температур зовнішнього повітря $15 \ldots 17{ }^{\circ} \mathrm{C}$ i склало 0,32 (рис.9).

У цій серії експериментальних досліджень ВАХА 3 початковим (заправним) тиском 15 бар не працював вже при температурі повітря навколишнього середовища, починаючи 3 температури $22{ }^{\circ} \mathrm{C}$ - без обдуву теплорозсіюючих елементів і 3 температури $24{ }^{\circ} \mathrm{C}-3$ обдувом.

3 урахуванням отриманого досвіду моделювання та результатів експериментальних досліджень були запропоновані перспективні енергозберігаючі схеми ВАХА і способи їх управління.

Зокрема, запропонований оригінальний спосіб управління ВАХА, в якому додатково контролюють температуру зовнішнього повітря і залежно від іiі чисельного значення змінюють тиск парогазового компонента робочого тіла у ВАХА, причому зі зменшенням температури зовнішнього повітря тиск знижують за рахунок відбору з ВАХА і наступного окремого блокування частини парогазового компоненту робочого тіла, а при збільшенні температури зовнішнього повітря тиск збільшують за рахунок повернення блокованого парогазового компонента робочого тіла у ВАХА, при цьому тиск у ВАХА контролюють побічно по тиску окремо блокованого парогазового компонента робочого тіла, враховуючи при цьому і температуру блокованого парогазового компонента робочого тіла.

Джерелом високої температури у ВАХА може служити генераторний вузол 3 робочою температурою до $170{ }^{\circ} \mathrm{C}$, а джерелом низької температури - зовнішнє повітря або конструктивні неенергонавантажені елементи АХП, наприклад, корпус ХК. Зміст запропонованого способу управління ілюструється рисунками 10, 11.

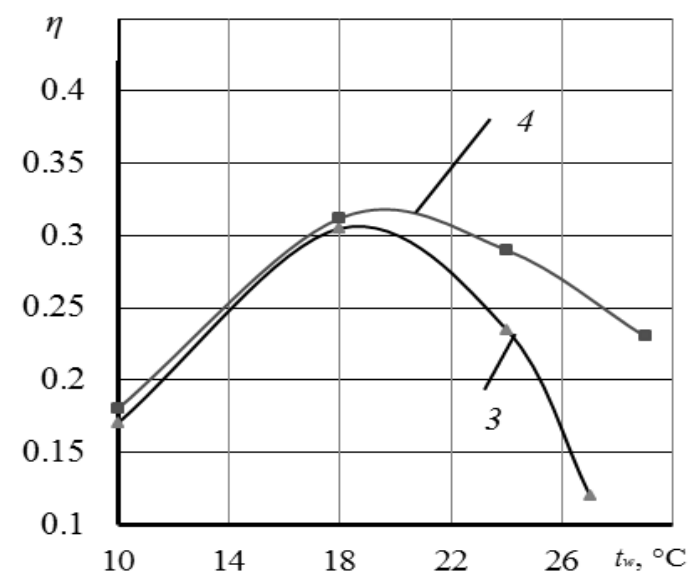

Рисунок 7 - Залежність середньодобового теплового коефіцієнта об'єкту дослідження від температури повітря в приміщенні при номінальному тепловому навантаженні 110 Вт і позиційному управлінні. Робочий тиск в системі 17,5 бар: 3 - робота без обдуву теплорозсіюючих елементів; 4 - робота $з$ обдувом теплорозсіюючих елементів. 


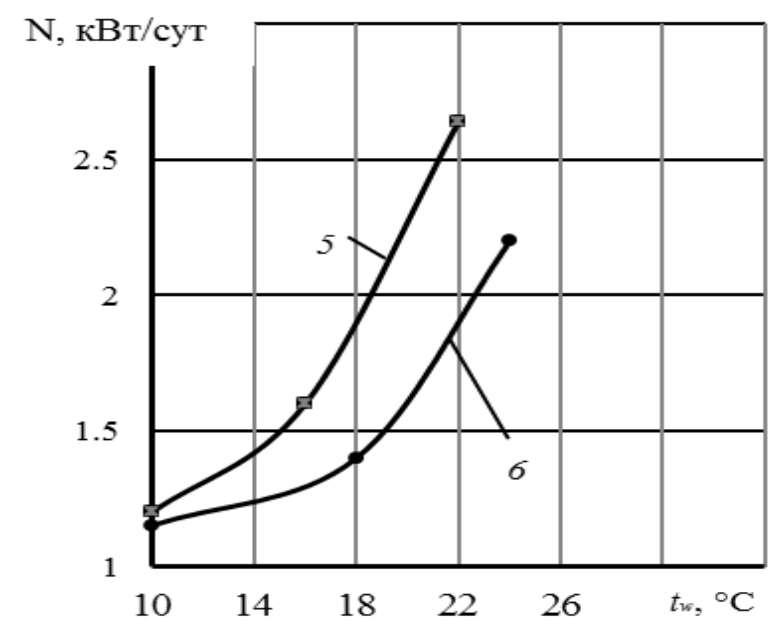

Рисунок 8 - Залежність добового енергоспоживання об'єкту дослідження від температури повітря в приміщенні. Робочий тиск в системі 15 бар. Режим роботи позиційний: 5 - робота без обдуву теплорозсіюючих елементів; 6 - робота з обдувом теплорозсіюючих елементів.

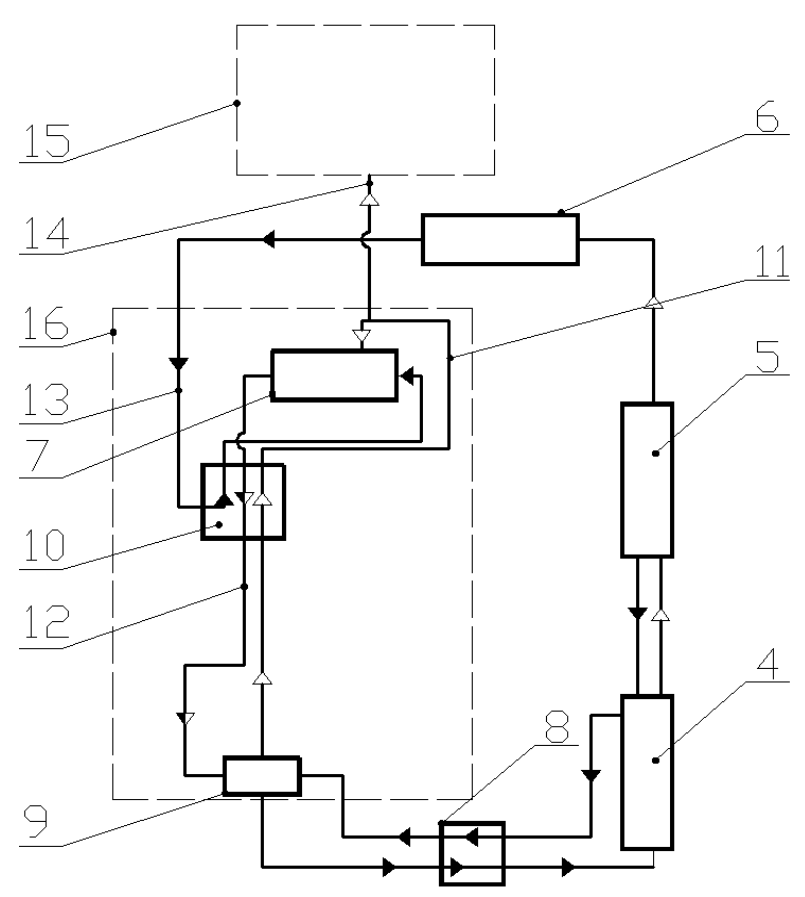

Рисунок 10 - Загальний вигляд ВАХА для реалізації запропонованого способу: 4 - генератор ВАХА; 5 дефлегматор; 6 - конденсатор; 7 - випарник; 8 - регенеративний рідинний теплообмінник; 9 - абсорбер; 10 - регенеративний трьох поточний теплообмінник; 11, 12 - відповідно підйомний і опускний канали парогазової суміші; 13 - канал рідкого аміаку; 14 - канал регулювання тиску; 15 - систему регулювання тиску (CPT).

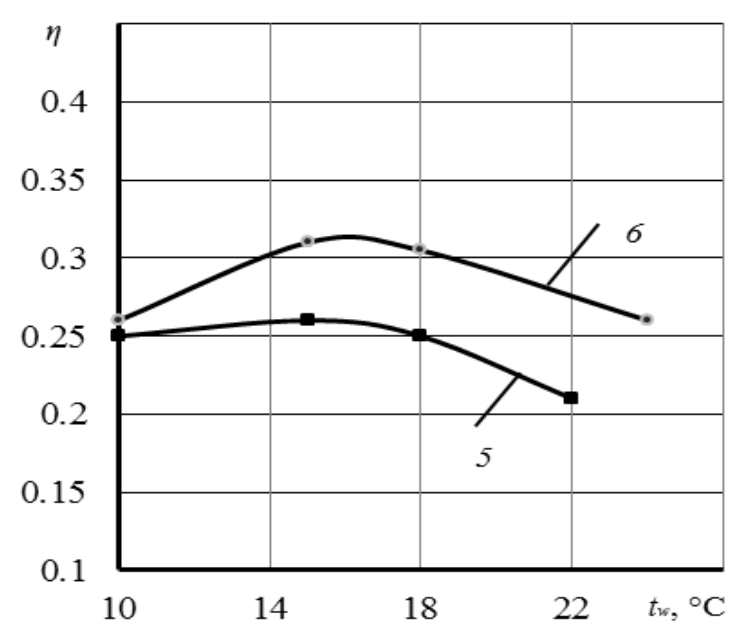

Рисунок 9 - Залежність середньодобового теплового коефіцієнта об'єкту дослідження від температури повітря в приміщенні при номінальному тепловому навантаженні 110 Вт і позиційному управлінні. Робочий тиск в системі 15 бар: 5 - робота без обдуву теплорозсіюючих елементів; 6 - робота $з$ обдувом теплорозсіюючих елементів.

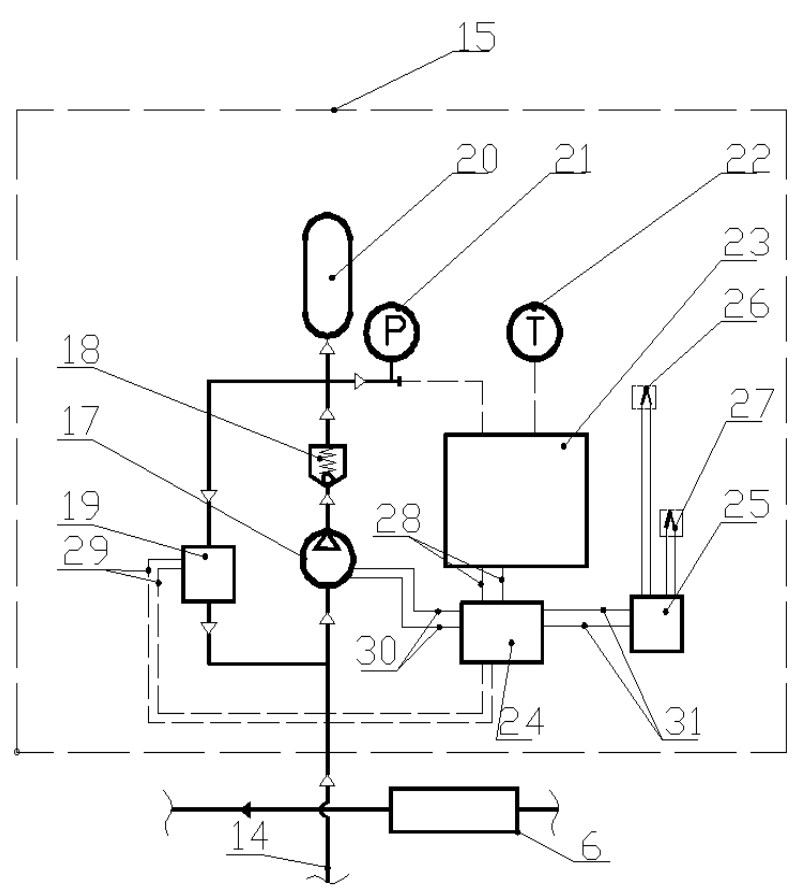

Рисунок 11 - Приклад системи управління для реалізації запропонованого способу: 14 - канал регулювання тиску; 15 - СРТ; 17 - компресор газу; 18 - зворотний клапан; 19 - запірний вентиль; 20 - ресивер газу; 21 - датчик тиску; 22 - датчик температури; 23 - управляючий блок СРТ; 24 - блок живлення; 25 - джерело електричної енергії, 26, 27 - холодний і гарячий спаї; 28 -31 силові магістралі. 
Для повної автономності роботи ВАХА 3 СРТ 15 запропоновано оснастити термоелектричним генератором 25, працюючим на різниці температур між зовнішнім повітрям і генератором ВАХА 4.

Позитивним моментом при використанні запропонованого способу управління стане зниження енергоспоживання при роботі АХП в широкому діапазоні температур зовнішнього повітря за рахунок зниження теплових втрат при транспортуванні потоків робочого тіла між елементами ВАХА 3 і за рахунок зниження необоротності при інтенсифікації внутрішніх процесів тепломасообміну у разі зниження тиску.

Як показує термодинамічний аналіз циклів BAXA, для енергоефективної роботи ВАХА в широкому діапазоні температуру зовнішнього повітря потрібно не лише змінювати рівень тиску в системі, але і змінювати склад рідкого робочого тіла. У сучасній конструкції ВАХА зробити неможливо.

В зв'язку 3 цим був запропонований оригінальний спосіб енергозберігаючого управління ВАХА шляхом регулювання складу рідкої фази ВАР. Пропонується в зоні транспортного каналу рідкого аміаку між конденсатором і випарником встановити мембранний ресивер, який може змінювати свій внутрішній об'єм. Змінюючи об'єм ресивера рідкого аміаку, можна регулювати склад ВАР, циркулюючого між генератором і абсорбером BAXА. Це дозволяє при знижених температурах навколишнього середовища і тисках в системі збільшувати долю аміаку в ВАР. У цьому випадку знижується теплове навантаження на генератор ВАХА при незмінних умовах роботи випарника, не менше, ніж на $30 \%$.

\section{Висновки}

1. Показано, що:

a) із зростанням температури охолоджувального середовища повинні збільшуватися і температури гріючого середовища і повний тиск в системі і навпаки;

б) мінімальна температура кінця кипіння в генераторі відповідає мінімальній зоні дегазації в абсорбері;

в) при реалізації циклів ВАХА $є$ режими з максимальною енергетичною ефективністю в практичних діапазонах температур охолоджуючого середовища (від 10 до $32{ }^{\circ} \mathrm{C}$ ) і об'єктів охолодження (від мінус 25 до мінус $5{ }^{\circ} \mathrm{C}$ ), а для їх реалізації, необхідно підбирати певну комбінацію складу робочого тіла і температури гріючого джерела.

2. Розроблена методика перевірочного розрахунку змієвикового противоточного абсорбера, в основі якого лежить математична модель процесів тепло- і масообміну. Показано, що при зниженні тиску в системі має місце і зниження інтенсивності процесу тепломасопереносу в абсорбері ВАХА, але за рахунок зниження витрати циркулюючої ПГС при низьких температурах зовнішнього повітря абсорбер виконує функцію очищення ПГС в КПЦ.

3. Із зростанням тиску в системі ВАХА від 15 до 20 бар інтенсивність процесів тепломасообміну при випаровуванні аміаку в парогазове середовище знижується в усьому діапазоні режимних параметрів. Так, значення коефіцієнтів масообміну знижуються в $1,75 \ldots 1,78$, а коефіцієнтів теплообміну - в 2,71...2,88 разів.
4. При зниженні тиску в системі спостерігається i зниження питомих енерговитрат в генераторі ВАХА. Так, при зниженні тиску від 20 бар до 12 бар питомі витрати тепла на випаровування 1 кг аміаку знижуються на $7,8 \%$.

5. Проведені дослідження абсорбційного холодильника АШ -160 з П-подібною аміачною ТТ в низькотемпературному відділенні (НТВ) підтвердили перспективність напрямку застосування теплових труб для підвищення енергетичних і експлуатаційних характеристик холодильників з ВАХА - знижується рівень температур в НТВ до мінус $21 \ldots$ мінус $18{ }^{\circ} \mathrm{C}$, а в ХК - до мінус $2,7^{\circ} \mathrm{C}$ при температурі навколишнього повітря 32 ${ }^{\circ} \mathrm{C}$, а холодильний прилад переходить 3 класу «**» в клас «***».

6. Показано, що застосування систем вимушеного обдуву теплорозсіюючих елементів дає енергетичний ефект тільки при охолодженні конденсатора і абсорбера BAXА, при цьому необхідно виключити попадання повітряних потоків на підйомну ділянку дефлегматора і елементи генераторного вузла. Найбільший енергетичний ефект обдув теплорозсіюючих елементів дає при підвищених температурах навколишнього середовища - від 7 до $39 \%$.

7. Проведені дослідження абсорбційного холодильника "Київ-410" АШ-160 показали енергетичну ефективність способу зміни тиску у ВАХА при відповідній зміні температури зовнішнього повітря. Такий спосіб дозволяє підтримувати практично на однаковому рівні тепловий коефіцієнт апаратів з ВАХА в усьому діапазоні робочих температур (від 10 до $32^{\circ} \mathrm{C}$ ).

8. Запропонований спосіб підвищення енергетичної ефективності ВАХА за рахунок зміни складу циркулюючого між абсорбером і генератором ВАР, що знизить кількість баластного аміаку в ПГС і підвищить холодопродуктивність випарника.

\section{Література}

1. Закон України № 4227-VI від 22 грудня 2011 року. Про продовольчу безпеку України.

2. Прилади холодильні побутові. Експлуатаційні характеристики та методи ви-пробувань: - введ. 1995-07-20. - К. : Держстандарт України, 1996. - 22 с. - (Національний стандарт України).

3. Очеретяный, Ю. А. Исследование влияния качки судна на процессы гравитационного пленочного течения рабочего тела в теплообменных элементах абсорбционных холодильных агрегатов (АХА) / Ю. А. Очеретяный, В. Х. Кирилов, А. С. Титлов // Наукові праці ОНАХТ. - 2010 - Вип.38 - Т.2. - С.365-372.

4. Старостенко, И. В. Методы и устройства для бесконтактного импедансно-резонансного контроля; виды высокоэффективной электрохимической обработки, включая технику скоростной металлизации и получение воды из воздуха // Молодой ученый. - 2018. №22. - C. 178-187. https://moluch.ru/archive/208/50919/ 5. Тітлов, О. С. Науково-технічні основи створення енергозберігаючих побутових абсорбційних холодильних приладів / О.С. Тітлов, М. Д. Захаров // Наукові праці Одеської національної академії харчових техноло-гій. - 2009. - № 35. - Т.1. - С. 113-127. 
6. Ищенко, И. Н. Моделирование циклов насосных и безнасосных абсорбционных холодильных агрегатов / И. Н. Ищенко // Наукові праці Одеської національної академії харчових технологій. - 2010. - № 38. -Т.2. - С. 393-405.

7. Ищенко, И. Н. Моделирование процессов тепло- и массообмена в противоточном змеевиковом абсорбере /
И. Н. Ищенко, А. С. Титлов // Харчова наука і технологія. -2010 . - № 3. - С. 125-128.

8. Ищенко, И. Н. Результаты экспериментальных исследований абсорбционных холодильных приборов, работающих в климатических условиях класса $\mathrm{SN}^{*}$ / И. Н. Ищенко, А. С. Титлов, Г. М. Олифер // Харчова наука і технологія. - 2010. - № 4. - С. 100-103.

\title{
Improvement of regime parameters of water-absorbing ammonia refrigeration units operating in a wide range of ambient temperatures
}

\author{
I. M. Ishchenko, O. S. Titlov ${ }^{1 凶}$ \\ Odessa National Academy of Food Technologies, 112 Kanatnaya St., Odessa, 65039, Ukraine \\ ORCID: ${ }^{1}$ 0000-0003-1908-5713; $\triangle$ e-mail: titlov1959@gmail.com
}

\begin{abstract}
Absorption refrigerators can be widely used when working in a wide range of ambient air temperatures. To solve a number of technical problems in optimizing energy characteristics, theoretical studies of cycles and processes of heat and mass transfer were performed in a number of key elements (evaporator, absorber, generator), as well as experimental studies of the production model of the Vasil'kovsky refrigerator plant. It is shown that a change in the composition of the working fluid (inert gas pressure) with a change in outside air temperature allows stabilizing energy consumption, despite a number of negative effects on operating parameters. According to the results of the research, two energy-efficient ways of managing water-absorption absorption refrigeration units were proposed. Shown, that: a) as the ambient air temperature rises, both the temperatures of the heating medium and the total pressure in the system and vice versa should increase; b) the minimum end boiling point in the generator corresponds to the minimum degassing zone in the absorber; c) when implementing WARA cycles there are modes with maximum energy efficiency in practical temperature ranges of the cooling medium (from 10 to $32^{\circ} \mathrm{C}$ ) and cooling objects (from minus 25 to minus $5{ }^{\circ} \mathrm{C}$ ), and for their realization, it is necessary to select a certain combination of composition the working fluid and the temperature of the heating source. A methodology has been developed for testing the calculation of a coil countercurrent absorber, which is based on a mathematical model of heat and mass transfer processes. It is shown that with a decrease in pressure in the system, a decrease in the intensity of the heat and mass transfer process in the WARA absorber takes place, but by reducing the flow rate of the circulating gas-vapor mixture at low external air temperatures, the absorber performs the function of cleaning it in the natural circulation circuit. With an increase in pressure in the WARA system from 15 to 20 bar, the intensity of heat and mass transfer processes during the evaporation of ammonia into the vaporgas medium decreases throughout the entire range of operating parameters. Thus, the values of the mass transfer coefficients decrease by $1.75 \ldots 1.78$, and the heat transfer coefficients - by $2.71 \ldots 2.88$ times. With a decrease in pressure in the system, a decrease in the specific energy consumption in the WARA generator is also observed. Thus, with a decrease in pressure from 20 bar to $12 \mathrm{bar}$, the specific heat consumption for evaporation of $1 \mathrm{~kg}$ of ammonia is reduced by 7.8 $\%$. Studies of the absorption cooler ASH-160 with an ammonia heat pipe in the low-temperature compartment (LTC) confirmed the promise of using heat pipes to improve the energy and performance characteristics of refrigerators with WARA - the temperature in LTC decreases to minus $21 \ldots$ minus $18{ }^{\circ} \mathrm{C}$, and in the refrigerating chamber - to minus 2.7 ${ }^{\circ} \mathrm{C}$ at an ambient air temperature of $32{ }^{\circ} \mathrm{C}$, and the refrigeration appliance moves from the class $" * * *$ to the class $" * * * "$. It is shown that the use of forced blowing systems with heat-dissipating elements gives an energy effect only when the condenser and absorber WARA are cooled, and it is necessary to exclude the ingress of air flows to the lifting section of the dephlegmator and the elements of the generating unit. The highest energy effect of blowing over the heat-dissipating elements gives at elevated ambient air temperatures - from 7 to $39 \%$. Studies of the absorption refrigerator "Kiev-410" ASH-160 showed the energy efficiency of the method of changing the pressure in the WARA with a corresponding change in the outside air temperature. This method allows you to maintain almost the same level of thermal coefficient of WARA in the entire range of operating temperatures (from 10 to $32{ }^{\circ} \mathrm{C}$ ). A method is proposed for increasing the energy efficiency of the WARA by changing the composition of the circulating between the absorber and the generator of an ammonia-water solution, which will reduce the amount of ballast ammonia in the vapor-gas mixture and increase the cooling capacity of the evaporator.
\end{abstract}

Keywords: water-ammonia absorption cooling units; modeling of heat and mass transfer processes; thermodynamic cycles; energy saving; wide range of ambient temperatures

\section{References}

1. Zakon Ukrayiny № 4227-VI vid 22 hrudnya 2011 roku. Pro prodovol'chu bezpeku Ukrayiny.

2. Prylady kholodyl'ni pobutovi. Ekspluatatsiyni kharakterystyky ta metody vy-probuvan': - vved. 1995-07-
20. - K. : Derzhstandart Ukrayiny, 1996. - 22 s. (Natsional'nyy standart Ukrayiny).

3. Ocheretyanyy, YU. A. Yssledovanye vlyyanyya kachky sudna na protsessy hravytatsyonnoho plenochnoho techenyya rabocheho tela $\mathrm{v}$ teploobmennykh élementakh absorbtsyonnykh kholodyl'nykh ahrehatov (AKHA) / YU. 
A. Ochere-tyanyy, V. KH. Kyrylov, A. S. Tytlov // Naukovi pratsi ONAKHT. - 2010 - Vyp.38 - T.2. - S.365372.

4. Starostenko, I. V. Metody i ustroistva dlia beskontaktnogo impedansno-rezonansnogo kontrolia; vidy vysokoeffektivnoi elektrokhimicheskoi obrabotki, vkliuchaia tekhniku skorostnoi metallizatsii i poluchenie vody iz vozdukha // Molodoi uchenyi. — 2018. — №22. S. 178-187. https://moluch.ru/archive/208/50919/

5. Titlov, O. S. Naukovo-tekhnichni osnovy stvorennya enerhozberihayuchykh pobutovykh absorbtsiynykh kholodyl'-nykh pryladiv / O.S. Titlov, M. D. Zakharov // Naukovi pratsi Odes'koyi natsional'noyi akademiyi kharchovykh tekh-nolo-hiy. - 2009. - № 35. - T.1. - S. 113-127.

6. Yshchenko, Y. N. Modelyrovanye tsyklov nasosnykh y beznasosnykh absorbtsyonnykh kholodyl'nykh ahrehatov /
Y. N. Yshchenko // Naukovi pratsi Odes'koyi natsional'noyi akademiyi kharchovykh tekhnolohiy. - 2010. - № 38. -T.2. - S. 393-405.

7. Yshchenko, Y. N. Modelyrovanye protsessov teplo- y massoobmena v protyvotochnom zmeevykovom absorbere / Y. N. Yshchenko, A. S. Tytlov // Kharchova nauka i tekhnolohiya. - 2010. - № 3. - S. 125-128.

8. Yshchenko, Y. N. Rezul'taty éksperymental'nykh yssledovanyy absorbtsyonnykh kholodyl'nykh pryborov, rabotayushchykh v klymatycheskykh uslovyyakh klassa SN* / Y. N. Yshchenko, A. S. Tytlov, H. M. Olyfer // Kharchova nauka i tekhnolohiya. - 2010. - № 4. S. 100-103. 